\title{
Emended description of Anomalomyces (Ustilaginales), including Anomalomyces yakirrae sp. nov. on Yakirra pauciflora (Poaceae) from Australia
}

\author{
Roger G. Shivas ${ }^{1 *}$, Matthias Lutz ${ }^{2}$, Alistair R. McTaggart ${ }^{1} \&$ \\ Kálmán Vánky ${ }^{3}$
}

\begin{abstract}
${ }^{1}$ DAFF, Ecosciences Precinct, GPO Box 267, Brisbane, Qld 4001, Australia
${ }^{2}$ Evolutionäre Ökologie der Pflanzen, Institut für Evolution und Ökologie, University of Tübingen, Auf der Morgenstelle 1, D-72076 Tübingen, Germany

${ }^{3}$ Herbarium Ustilaginales Vánky (H.U.V.), Gabriel-Biel-Str. 5, D-72076 Tübingen, Germany

Received 5 December 2012 / Accepted 21 December 2012 / Published 11 January 2013

Shivas, R.G., Lutz, M., McTaggart, A.R. \& Vánky, K. 2013. Emended description of Anomalomyces (Ustilaginales), including Anomalomyces yakirrae sp. nov. on Yakirra pauciflora (Poaceae) from Australia. Mycobiota 1: 17-24. doi: 10.12664/mycobiota.2013.01.03
\end{abstract}

\begin{abstract}
An emended description of the genus Anomalomyces is given to accommodate a new species of smut fungus, Anomalomyces yakirrae, on Yakirra pauciflora (Poaceae) from Australia. The systematic placement of the fungus within the genus Anomalomyces is based on morphological characters and molecular data from two loci.
\end{abstract}

Key words: Anomalomyces panici, Basidiomycota, molecular phylogenetics, plant pathogens, smut fungi, taxonomy

\section{Introduction}

Anomalomyces Vánky, M. Lutz \& R.G. Shivas (2006) was established for a fungus producing sori in hypertrophied ovaries of Panicum (Poaceae). Anomalomyces is one of ten genera of smut fungi endemic to Australia (Lutz et al. 2012). Anomalomyces was characterised by sori that had a covered peridium without columella and were divided into irregular, incomplete compartments by a membrane of host and fungal origin. The brown spores were agglutinated in permanent spore balls with a layer of darkly pigmented cortex. Two distinct types of sterile cells between the spore balls were also present. Spore germination resulted in phragmobasidia that produced basidiospores laterally and terminally. The establishment

\footnotetext{
*Corresponding author: e-mail: Roger.Shivas@daff.qld.gov.au
} 
of Anomalomyces as a distinct genus was subsequently supported by molecular analyses (McTaggart et al. 2012b). Anomalomyces is monotypic represented by the type species $A$. panici Vánky, R.G. Shivas \& M. Lutz and a few collections on Panicum trachyrhachis from the Northern Territory, Australia (Vánky \& Shivas 2008).

In April 2011, a smut fungus was collected in the hypertrophied ovaries of Yakirra pauciflora in the arid tropical region of north-western Australia. The fungus was shown by morphological and molecular methods to represent a second species of Anomalomyces.

\section{Materials and methods}

The specimen examined in this study is listed below. The voucher specimen has been deposited in BRIP and H.U.V. The latter abbreviation refers to the personal collection of Kálmán Vánky, "Herbarium Ustilaginales Vánky” currently held at his home (GabrielBiel-Straßr 5, D-72076 Tübingen, Germany). Nomenclatural novelties were registered in MycoBank (www.MycoBank.org, Crous et al. 2004). The genetype concept follows the proposal of Chakrabarty (2010).

\section{Morphological examination}

Spore characteristics were studied using dried herbarium specimens. For light microscopy (LM) spores were suspended in a small droplet of lactic acid, covered with a cover glass, gently heated to boiling point to rehydrate the spores and expel air bubbles from the preparation, and studied at $1000 \times$ magnification.

\section{DNA extraction, PCR, and sequencing}

The methods of isolation of fungal material, DNA extraction, amplification of the ITS 1 and ITS 2 regions of the rDNA including the 5.8S rDNA (ITS, about $680 \mathrm{bp}$ ) and the $5^{5}$-end of the nuclear large subunit ribosomal DNA (LSU, about $650 \mathrm{bp}$ ), purification of PCR products, sequencing, and processing of the raw data followed Lutz et al. (2012). DNA sequences determined for this study were deposited in GenBank. GenBank accession numbers are KC184907/KC184906 (ITS/LSU).

\section{Phylogenetic analyses}

Taxa were selected to represent major clades of closely related genera recovered in previous systematic studies (Fig. 1) (Stoll et al. 2005; McTaggart et al. 2012b). Alignments of sequence data were undertaken with the MAFFT algorithm and were unedited (Katoh et al. 2009). Two phylogenetic assessment criteria were implemented: Bayesian inference using MrBayes (Huelsenbeck \& Ronquist 2001; Ronquist \& Huelsenbeck 2003) and maximum likelihood using RAxML (Stamatakis 2006) and PhyML (Guindon et al. 2010). Resulting trees were observed with FigTree (available at http://www.tree.bio.ed.ac.uk/software/ figtree/). Alignments and treefiles for all analyses are available at TreeBASE (13664).

The RAxML analyses were run with a rapid Bootstrap analysis (command $-\mathrm{f}$ a) using a random starting tree and 1000 maximum likelihood bootstrap replicates. The PhyML analyses were implemented using the ATGC bioinformatics platform (available at: http:// 


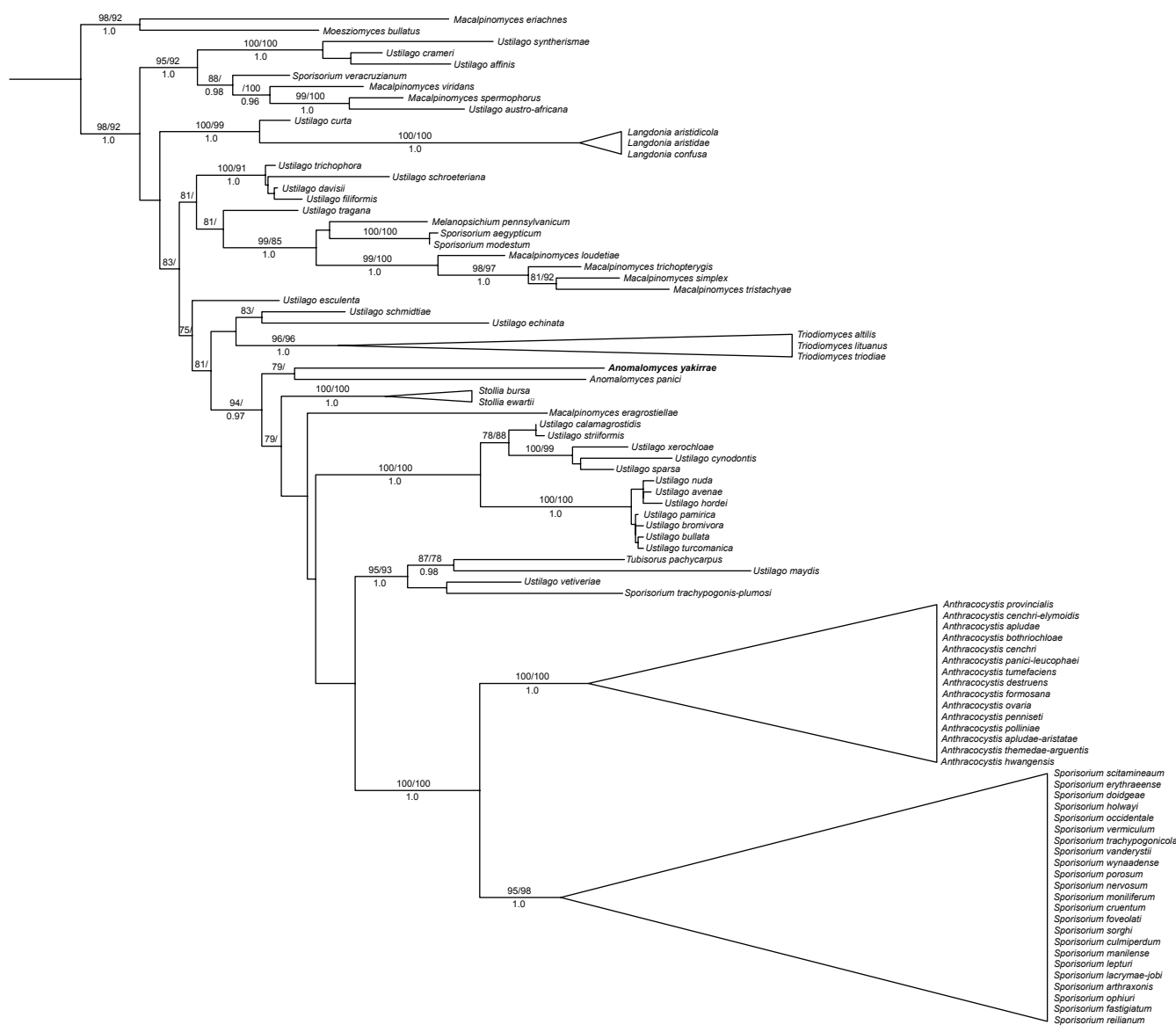

Fig. 1. Phylogram obtained from a maximum likelihood analysis of ITS and LSU loci in PhyML. PhyML aRLT values and Bootstrap values ( $\geq 70 \%)$ from 1000 bootstrap replicates in RAxML shown above nodes. Posterior probabilites from Bayesian inference $(\geq 0.95)$ below nodes

www.atgc-montpellier.fr/phyml/), with SPR tree improvement, and support obtained from an approximate likelihood ratio test (Anisimova et al. 2011).

MrBayes was used to conduct a Markov Chain Monte Carlo (MCMC) search in a Bayesian analysis. Two runs, each consisting of four chains, were implemented until the average standard deviation of split frequencies had reached 0.01 . The cold chain was heated at a temperature of 0.25 . Substitution model parameters were sampled every 100 generations and trees were saved every 5000 generations. A user-defined tree obtained from the maximum likelihood analyses was used as a starting point in the Bayesian analysis. Convergence of the Bayesian analysis was examined using the cumulative and comparative analyses in AWTY (Nylander et al. 2008). 


\section{Results}

The results of the morphological examination by light microscopy and SEM are included in the species description and Fig. 2. The molecular phylogenetic analyses (Fig. 1) recovered six well resolved genera - Anthracocystis, Langdonia, Sporisorium, Stollia, Triodiomyces and Ustilago s. str. - with strong phylogenetic support. Similar topologies were reconstructed by the three different phylogenetic packages. Relationships between the genera were not well-supported. Anomalomyces panici and A. yakirrae were recovered in a clade, but with weak support from the RAxML and Bayesian analyses. Anthracocystis and Sporisorium were recovered as sister genera with strong support.

\section{Discussion}

To date about 1,600 species of smut fungi (sub-phylum Ustilaginomycota) in about 90 genera are described, with almost half of these species infecting grasses (Vánky 2011). Most genera and species of smut fungi that occur on grasses were established on the basis of differences in morphology and host range. Shared morphological characters between some of the larger genera of smut fungi on grasses, e.g. Ustilago, Sporisorium, Tranzscheliella and Macalpinomyces, has made delimitation of genera and species placement problematic (McTaggart et al. 2012a).

The first large scale systematic studies for grass-infecting smut fungi were not able to identify characters that defined monophyletic groups (Stoll et al. 2003, 2005). Since then two new genera of smut fungi on grasses were described and named, Anomalomyces Vánky, M. Lutz \& R.G. Shivas (2006) and Tubisorus Vánky \& M. Lutz (2011). Each of these genera was established based on morphology combined with molecular phylogenetic analyses. More recently a systematic study by McTaggart et al. (2012b, c) determined synapomorphic characters that resolved the generic classification of some of the grass infecting smut fungi in the Ustilaginaceae. They introduced three new genera based on soral synapomorphies and host classification, namely Langdonia McTaggart \& R.G. Shivas, Stollia McTaggart \& R.G. Shivas and Triodiomyces McTaggart \& R.G. Shivas, and resurrected Anthracocystis Bref., to subdivide species of Sporisorium with filiform columellae, spore balls and fungal derived peridia. The suite of characters present in Anomalomyces was unique within the Ustilaginaceae and McTaggart et al. (2012b) maintained it as a separate genus.

Anomalomyces yakirrae and A. panici are morphologically similar in two respects. Firstly, each has a well-developed membrane of host and fungal origin that divides the sori into incomplete, irregular compartments. Secondly, each has spore balls that are covered in a dark brown amorphous cortex. The two species differ in that Anomalomyces yakirrae does not have the small $(<5.5 \mu \mathrm{m}$ diam.) dark olivaceous brown sterile cells found in $A$. panici. The dark brown layer that covers the spore balls is of fungal origin. This layer coats the apex and sides of the outermost cells in the spore balls. Exerting heavy pressure on the cover slip of microscope slide preparations separates this layer from the outermost cells, indicating that the layer provides structural integrity to the spore ball and protection for the spores. Vánky et al. (2006) provided an image of the young spore balls of Anomalomyces panici, 


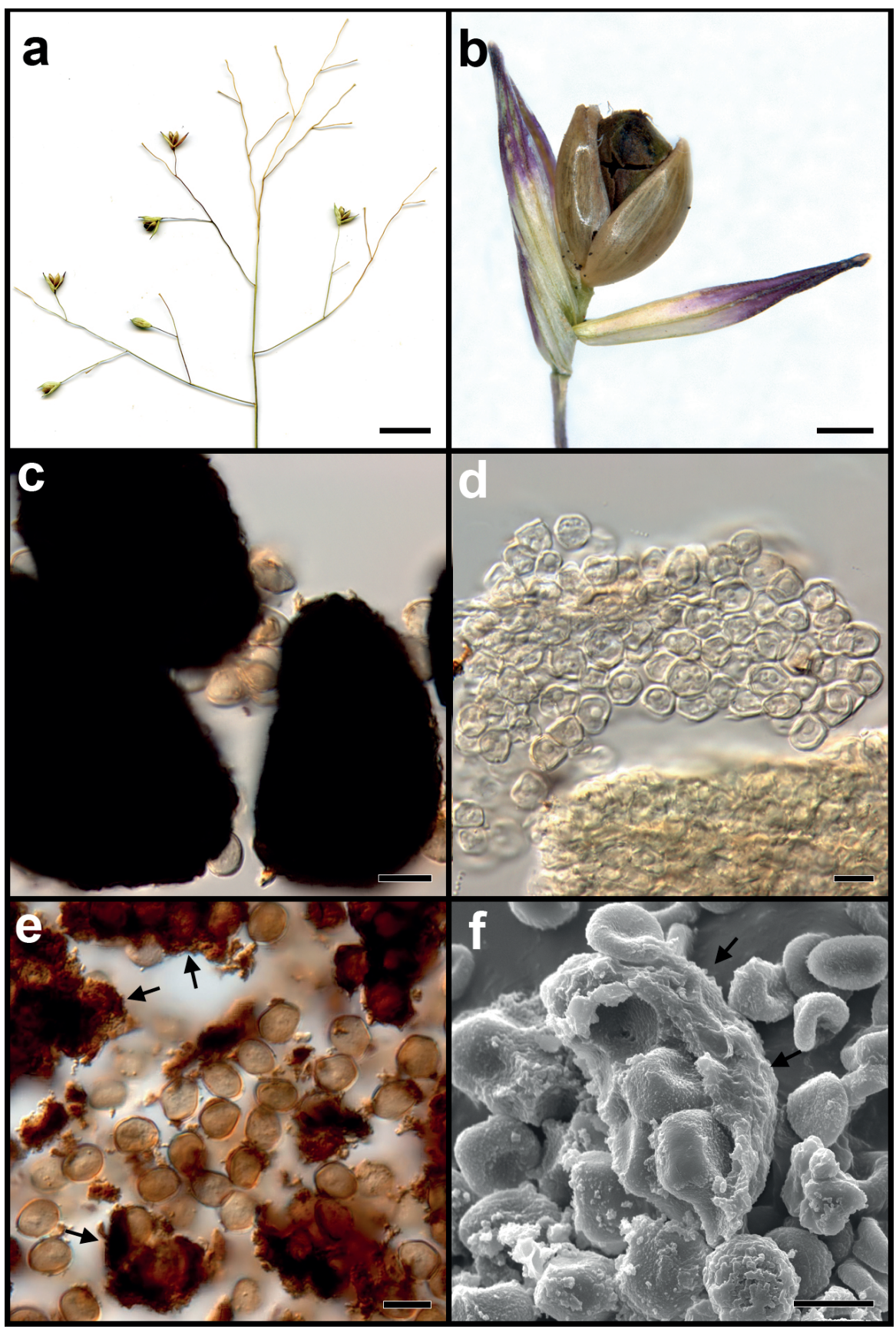

Fig. 2. Anomalomyces yakirrae: a - sori in some hypertrophied ovaries of Yakirra pauciflo$\mathrm{ra} ; \mathbf{b}$ - sorus; $\mathbf{c}-$ spore balls; $\mathbf{d}$ - sterile cells; $\mathrm{e}, \mathrm{f}$ - spores and portions of the broken cortex (arrowed) in crushed slide mount preparation under LM (left) and SEM (right). Bars: a $=1 \mathrm{~cm}, \mathrm{~b}=1 \mathrm{~mm}, \mathrm{c}-\mathrm{f}=10 \mu \mathrm{m}$ 
which shows that this surface layer develops at a very early stage from strongly modified, small, fungal cells as illustrated in the young spore ball in the middle of Fig. 4, p. 123.

The grass hosts of Anomalomyces yakirrae and A. panici are Yakirra and Panicum respectively. These two closely related genera of grasses, belong to the Paniceae tribe of the Panicoideae subfamily. The close relationship of these two grasses together with the shared morphological characters of Anomalomyces yakirrae and A. panici, indicates a close relationship between the two smut fungi.

The relationship between Anomalomyces yakirrae and A. panici is weakly supported by molecular data. Based solely on molecular data the establishment of a new genus for Anomalomyces yakirrae was an option, as the phylogentic analysis was neither supportive nor contradictory. We have chosen not to establish a new genus as soral morphology and host specificity suitably delimit Anomalomyces.

\section{Taxonomy}

The discovery of a second species of Anomalomyces, with only one kind of sterile cell between the spore balls, requires an emended generic description.

Anomalomyces Vánky, M. Lutz \& R.G. Shivas, Mycologia Balcanica 3: 120, 2006, emend. Vánky \& R.G. Shivas.

Sori in hypertrophied ovaries of Poaceae divided into compartments by membranes of host tissue permeated by hyphae, peridium of host and fugal tissue present, columella absent. Spores pigmented (brown, without violet or reddish tint), forming permanent spore balls. Outermost spores in the balls covered by a hard, darkly pigmented, amorphous cortex, formed by agglutinated, strongly modified fungal cells. Spore balls permanent, composed of pigmented (brown) spores, coated by the cortex. Sterile cells between the spore balls variable in morphology and frequency, of one or more types. Spore germination results in phragmobasidia producing basidiospores laterally and terminally.

Anomalomyces yakirrae R.G. Shivas, M. Lutz, A.R. McTaggart \& Vánky, sp. nov. $\quad$ Fig. 2 MycoBank \# MB 802389

Type in ovaries of Yakirra pauciflora (R. Br.) Lazarides \& R.D. Webster, Australia, Western Australia, $37 \mathrm{~km}$ SE of Kununurra, corner of Victoria Highway and Lake Argyle Road, 1557'48” S, 12857'53” E, alt. c. 135 m, 18.IV.2011, coll. M.D.E. \& R.G. Shivas, Y.C. Tran, T. \& K. Vánky (holotype, BRIP 54 404; isotype, H.U.V. 21 918).

Sori (Figs 2a, b) in some ovaries of an inflorescence, ovoid, $1.5-2 \times 2-3.5 \mathrm{~mm}$, partly hidden by the floral envelopes, covered by the dark brown peridium composed of host and fungal cells, at maturity ruptures to expose the blackish brown, semi-agglutinated to granular-powdery mass of spore balls. Columella absent, but weakly developed membrane of host and fungus origin present in some sori. Spore balls (Fig. 2c) subglobose, ovoid, ellipsoidal, elongated to subpolyhedrally irregular, 30-90 $\times 40-150 \mu \mathrm{m}$, dark reddish brown or opaque, composed of tens to hundreds of tightly packed spores that separate under pressure, covered in a $2.5-3.5 \mu \mathrm{m}$ thick, dark reddish brown amorphous cortex. 
Spores (Figs 2c, e, f) subglobose, ellipsoidal to subpolyhedrally slightly irregular, 7-9.5 $\times 8-12 \mu \mathrm{m}$, pale yellowish brown; wall even, c. $0.5 \mu \mathrm{m}$ thick, apparently smooth to very finely verruculose. Sterile cells between the spore balls, in irregular groups or single, globose, ellipsoidal or slightly irregular, 5.5-10.5 $\mu \mathrm{m}$ long, hyaline, sparse to abundant; wall evenly c. $0.5 \mu \mathrm{m}$ thick, apparently smooth to very finely punctate.

The ITS/LSU genetype sequences are deposited in GenBank with the accession numbers KC184907/KC184906, respectively.

On Poaceae: Yakirra pauciflora. Known only from the type locality in north-western Australia.

\section{Key to the species of Anomalomyces}

1 Spore balls 30-200 $\mu \mathrm{m}$ long; sterile cells of two types, large and small, 8-15, respectively

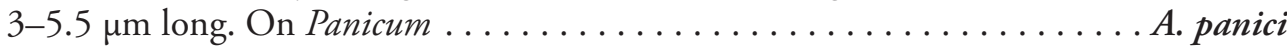

$1^{*}$ Spore balls $40-150 \mu \mathrm{m}$ long, sterile cells of one type, 5.5-10.5 $\mu \mathrm{m}$ long. On Yakirra A. yakirrae

Acknowledgements. We thank Michael Weiß, Sigisfredo Garnica, and Robert Bauer (Tübingen) for providing facilities for molecular analyses.

\section{References}

Anisimova, M., Gil, M., Dufayard, J.-Fo., Dessimoz, C. \& Gascuel, O. 2011. Survey of branch support methods demonstrates accuracy, power, and robustness of fast likelihood-based approximation schemes. - Systematic Biology 60: 685-699. doi: 10.1093/sysbio/syr041

Chakrabarty, P. 2010. Genetypes: a concept to help integrate molecular phylogenetics and taxonomy. Zootaxa 2632: 67-68.

Crous, P.W., Gams, W., Stalpers, J.A., Robert, V. \& Stegehuis, G. 2004. MycoBank: an online initiative to launch mycology into the $21^{\text {st }}$ century. - Studies in Mycology 50: 19-22.

Guindon, S., Dufayard, J.F., Lefort, V., Anisimova, M., Hordijk, W. \& Gascuel, O. 2010. New algorithms and methods to estimate maximum-likelihood phylogenies: assessing the performance of PhyML 3.0. - Systematic Biology 59: 307-321. doi: 10.1093/sysbio/syq010

Huelsenbeck, J.P. \& Ronquist, F. 2001. MRBAYES: Bayesian inference of phylogenetic trees. Bioinformatics 17: 754-755. doi: 10.1093/bioinformatics/17.8.754

Katoh, K., Asimenos, G. \& Toh, H. 2009. Multiple alignment of DNA sequences with MAFFT. - In: D. Posada (ed.). Bioinformatics for DNA sequence analysis. Numana Press. Chapter 3. Pp. 39-64. Humana Press. doi: 10.1007/978-1-59745-251-9_3 
Lutz, M., Vánky, K. \& Piątek, M. 2012. Shivasia gen. nov. for the Australasian smut Ustilago solida that historically shifted through five different genera. - IMA Fungus 3: 143-154. doi: 10.5598/ imafungus.2012.03.02.06

McTaggart, A.R., Shivas, R.G., Geering, A.D.W., Vánky, K. \& Scharaschkin, T. 2012a. A review of the UstilagoSporisorium-Macalpinomyces complex. - Persoonia 29: 55-62. doi: 10.3767/003158512X660283

McTaggart, A.R., Shivas, R.G., Geering, A.D.W., Vánky, K. \& Scharaschkin, T. 2012b. Soral synapomorphies are significant for the systematics of the Ustilago-Sporisorium-Macalpinomyces complex (Ustilaginaceae). - Persoonia 29: 63-77. doi: 10.3767/003158512X660562

McTaggart, A.R., Shivas, R.G., Geering, A.D.W., Vánky, K. \& Scharaschkin, T. 2012c. Taxonomic revision of Ustilago, Sporisorium and Macalpinomyces. - Persoonia 29: 116-132. doi: 10.3767/003158512X661462

Nylander, J.A.A., Wilgenbusch, J.C., Warren, D.L., Swofford, D.L. 2008. AWTY (are we there yet?): a system for graphical exploration of MCMC convergence in Bayesian phylogenetics. - Bioinformatics 24: 581-583. doi: 10.1093/bioinformatics/btm388

Ronquist, F. \& Huelsenbeck, J.P. 2003. MrBayes 3: Bayesian phylogenetic inference under mixed models. - Bioinformatics 19: 1572-1574. doi: 10.1093/bioinformatics/btg180

Stamatakis, A. 2006. RAxML-VI-HPC: Maximum likelihood-based phylogenetic analyses with thousands of taxa and mixed models. - Bioinformatics 22: 2688-2690. doi: 10.1093/bioinformatics/btl446

Stoll, M., Piepenbring, M., Begerow, D. \& Oberwinkler, F. 2003. Molecular phylogeny of Ustilago and Sporisorium species (Basidiomycota, Ustilaginales) based on internal transcribed spacer (ITS) sequences. - Canadian Journal of Botany 81: 976-984. doi: 10.1139/b03-094

Stoll, M., Begerow, D. \& Oberwinkler, F. 2005. Molecular phylogeny of Ustilago, Sporisorium, and related taxa based on combined analyses of rDNA sequences. - Mycological Research 109: 342-356. doi: $10.1017 /$ S0953756204002229

Vánky, K. 2011('2012'). Smut fungi of the world. American Phytopathological Society, St Paul, Minnesota, USA.

Vánky, K. \& Lutz, M. 2011. Tubisorus, a new genus of smut fungi (Ustilaginomycetes) for Sporisorium pachycarpum. - Mycologia Balcanica 8: 129-135.

Vánky, K. \& Shivas, R.G. 2008. Fungi of Australia: the smut fungi. ABRS, Canberra; CSIRO Publishing, Melbourne.

Vánky, K., Lutz, M. \& Shivas, R.G. 2006. Anomalomyces panici, new genus and species of Ustilaginomycetes from Australia. - Mycologia Balcanica 3: 119-126. 